\title{
An Investigation of the Relationship Between Job Satisfaction, Job Stress and Organizational Citizenship Behavior: A Research on Librarians in Nigerian University Libraries
}

\author{
Ikonne, Chinyere N., Ph.D ${ }^{1}$, Madukoma, Ezinwanyi, Ph.D ${ }^{2}$ \\ Department of Information Resources Management, Babcock University
}

\begin{abstract}
This study was carried out with the intension of understanding job satisfaction, job stress and organizational citizenship behavior of librarians in selected South-West Nigerian University libraries. Survey research design was used for the study. The population consisted of 109 librarians and total enumeration was used so as to ensure that all members of the population were used for the study. Structured questionnaire was employed for data collection and data collected were analyzed using frequency and percentage counts. The findings from the study revealed that the majority of the respondents were satisfied with their jobs. A greater numbers of them also agreed positively on the statements of organizational citizenship behavior which shows that they are engaged in organizational citizenship behaviors in their various libraries. As regards job stress, it was shown that much work pressure, work interfering during personal or family time; as well as the challenges of coping with technology were their major sources of job stress. The hypotheses revealed that there is positive significant relationship between job satisfaction and job stress and between job satisfaction and organizational citizenship behavior. However, a negative relationship was perceived to exist between job stress and organizational citizenship behavior.
\end{abstract}

Keywords: Job satisfaction, Job Stress, Organizational citizenship behavior, Librarian, South-West Nigeria, University libraries

\section{Introduction}

The subject of job satisfaction, job stress, and organizational citizenship behavior has been studied by many scholars in the fields of organizational behavior, organizational psychology and human resource management as a result of their impacts on job related behaviors. Job satisfaction (JS) is a frequently studied subject in work and organizational literature and the interest has been driven by the fact that experts believe that the trends of job satisfaction can affect labor market behavior. Job satisfaction has been widely reported as a powerful motivator that influences employees' attitude in relation to their jobs [1]. It also exerts huge influence on performance, retention, employee turnover, as well as work absenteeism. Being linked to the emotional feeling of employees and their work, [2] argues that job satisfaction could be pictured as one of the key elements that lead to the success of any organization. Therefore, if employees are not satisfied with their jobs or with job situation, stress may likely to set in and possibly they might not have any interest in organizational citizenship behavior

In the course of examining what predicts job satisfaction of the librarians in the university libraries in Southern Nigeria, [3] found job security, satisfactory relationships with supervisor, with interaction with colleagues, information user/customer/client, job duties/schedules and job challenges are predictors of job satisfaction for the librarians. Attractive salaries and wages were found to have led to the job satisfaction of librarians in the studies of [4] and 15]. Some of the most important job satisfaction facets discovered by [6] in their study of cataloger librarians include benefits package, relationships with coworkers, opportunities to learn new skills, fair treatment, respected opinions respected and wish to be supported by the administration.
On the other hand, stress is a process in which environmental events or forces seem to threaten the wellbeing of an individual in the society. Job or occupational stress has attracted many research interests and [7] and [8] claim that it is considered as a major concern in the occupational safety and health aspect as well as in organizational well-being. There are levels of job stress and as have been argued by Jex, 1998 (in [9]) and [10], stressful job stress is dysfunctional and decreases commitment and productivity and increases absenteeism. The cost of jobrelated stress is evaluated at 20 billion Euros for the European community and 300 billion dollars for the United States, according to [10]. Based on these, [11] contends that the negative implications of job stress are challenges to both employers and workers.

Techno-stress is another force which has also been identified as one of the job stressors for librarians. According to Harper, (2000) (in [12]), there are two forms of techno-stress affecting librarians, namely, the physical and the psychological forms. The physical forms of techno-stress come in the forms of headache, back strain, eye strain, repetitive strain injuries such as carpal tunnel syndrome, and muscular dysfunction, information overload, overidentification with technology, under work, excessive routine jobs, and feelings of job insecurity. Kupersmith 2003 (in [13]) and [14] argue that the usage of computer integrated system, CD-ROMs and multiple databases, the Internet and World Wide Web, and the rapid change of information technology have brought much amount of stress on librarians. The BBC News of January 2006 reports that working in a library is the most stressful job of all. According to psychologist Saqib Saddiq on the BBC news, librarians are unhappy with their workplace as their jobs are repetitive and unchallenging. Librarians also complained 


\section{International Journal of Science and Research (IJSR) \\ ISSN (Online): 2319-7064}

Index Copernicus Value (2013): 6.14 | Impact Factor (2015): 6.391

about their physical environment, noting that they were sick of being stuck between book shelves all day; that their skills were not used, and that they had little control over their career [15].

According to [16], not many studies on stress have been done in the libraries. However, [17] looked on the causes and effects of job related stress among Polytechnic librarians in Delta State, Nigeria and found out that pressure from management/bosses, poor work environment, excess workload, inadequate support system, challenges in coping with new technology and lack of supervision were causes of job stress. In his study, [18] identified unsuitable work environment caused by poor ergonomics, poor job incentives or rewards and poor interaction with other staff as sources of work-related stress among librarians and information professionals in a Nigerian University. Caputo (1991) (in [16]) reviewed seven studies from the 1980's on librarian burnout. Stressors identified were frequent technological changes, heavy workloads, and the constant need for speed. [19] conducted a survey of librarians and stress and the findings were that $77 \%$ of the respondents stated that they felt stressed at work.

Finally, organizational citizenship behavior (OCB) has been described by [20] as several elements of work activity not fully denoted by the traditional concept of job performance, which, according to [21] enhance organizational effectiveness. This behavior is discretionary, not directly or explicitly recognized by the formal reward system. Some researchers such as [22] have posited that the study of citizenship behavior is hinged on social exchange theory which argues that people reciprocate the advantages they receive from their organization. But for [23], citizenship behavior is an aspect of job performance while [20] refers it to several elements of work activity not fully denoted by the traditional concept of job performance. They are behaviors that arise rather from personal choices and voluntary efforts of employees such that its omission is not generally understood as punishable.

As has been explained by [24], organization citizenship behaviors (OCBs) have a variety of facets which have been identified as altruism, courtesy, sportsmanship, conscientiousness and civic virtue. Altruism means that employees help others with organizationally relevant tasks. Courtesy has to do with treating others with respect while sportsmanship implies that employees have a positive attitude and are willing to tolerate less than ideal circumstances without complaining. Conscientiousness is a discrete behavior such as obeying rules and regulations, not taking extra breaks, and working extra-long days. Finally, civic virtue means that employees responsibly participate in, and are concerned about, the welfare of the company [25].

Evidence from the literature has revealed that there are very few studies on stress in the libraries. In addition, it is has also been shown there is death literature on the relationship between job stress and organizational citizenship behavior of librarians in Nigeria. These observations have led to this study with the hope that the findings will add in filling the existing gap there may be in the literature.

\section{Objective of the Study}

The purpose of the study is to examine job satisfaction, job stress and organizational citizenship behavior of librarians in selected University libraries in Nigerian. Therefore, the specific objectives are to:

1) Find out the factors that predict job satisfaction of librarians in selected University libraries in Nigeria.

2) Determine factors that contribute to job stress of librarians in selected University libraries in Nigeria.

3) Ascertain the opinions of librarians regarding organizational citizenship behavior in selected University libraries in Nigeria.

\section{Hypotheses for the Study}

In order to attain the above mentioned objectives, the following hypotheses were developed and tested at 0.05 level of significance.

1) There is no significant relationship between job satisfaction and job stress of librarians in Nigerian Universities libraries

2) There is no significant relationship between job satisfaction and organizational citizenship behavior of librarians in Nigerian Universities.

3) There is no significant relationship between job stress and organizational citizenship behavior of librarians in Nigerian Universities.

\section{Methodology}

This study adopted a descriptive survey research design. A structured questionnaire was employed to carry out the survey. Study population consisted of 109 librarians from the following University libraries: Babcock University library, Federal University of Agriculture Abeokuta library, Olabisi Onabanjo University library, and Tai Solarin University of Education. Total enumeration was used so as to ensure that all members of the population were used for the study. The questionnaire that measured job satisfaction statements was adapted from Minnesota job satisfaction questionnaire while the scale of [26] was used as the organizational citizenship behavior questionnaire.

\section{Presentation of Findings}

A total of 109 questionnaires were distributed and returned.

Tables 1: Demographic information of the respondents

\begin{tabular}{|c|c|c|c|c|c|c|}
\hline & & & Frequency & $\%$ & $\begin{array}{c}\text { Valid } \\
\%\end{array}$ & $\begin{array}{c}\text { Cumulative } \\
\%\end{array}$ \\
\hline \multirow[t]{3}{*}{ Gender } & \multirow[t]{3}{*}{ Valid } & Male & 49 & 45.0 & 45.0 & 45.0 \\
\hline & & Female & 60 & 55.0 & 55.0 & 100.0 \\
\hline & & Total & 109 & 100.0 & 100.0 & 0 \\
\hline \multirow{6}{*}{\begin{tabular}{|c|} 
Work \\
Experience \\
in years
\end{tabular}} & \multirow{6}{*}{ Valid } & $\begin{array}{c}\text { Under } 1 \\
\text { year }\end{array}$ & 9 & 8.3 & 8.3 & 8.3 \\
\hline & & $1-3$ years & 8 & 7.3 & 7.3 & 15.6 \\
\hline & & $3-5$ years & 24 & 22.0 & 22.0 & 37.6 \\
\hline & & $5-10$ years & 16 & 14.7 & 14.7 & 52.3 \\
\hline & & $\begin{array}{c}\text { Above } 10 \\
\text { year }\end{array}$ & 52 & 47.7 & 47.7 & 100.0 \\
\hline & & & 109 & 100.0 & 100.0 & \\
\hline
\end{tabular}




\section{International Journal of Science and Research (IJSR) \\ ISSN (Online): 2319-7064 \\ Index Copernicus Value (2013): 6.14 | Impact Factor (2015): 6.391}

Indication from Table 1 reveals that 49(45\%) of the respondents are male while $60(55 \%)$ are female. The table also discloses that $9(8.3 \%)$ of the respondents have work experience less than 1 year, $8(7.3 \%)$ have work experience of 1-3years, $24(22 \%)$ have experience of 3-5years,
$16(14.7 \%)$ have experience of 5-10years, while 52(47.7\%) have $\%$ of experience of above 10years. This implies that majority of the respondents have work experience of above 10 years.

Table 2: Job Satisfaction

\begin{tabular}{|l|l|l|l|c|c|c|}
\hline$S N$ & \multicolumn{1}{|c|}{ Statement } & $V S$ & $S$ & $U D$ & $D$ & $V D$ \\
\hline 1 & Satisfaction with my relationship with my supervisor & $34(31.2 \%)$ & $75(68.8 \%)$ & 0 & 0 & 0 \\
\hline 2 & I receive good cooperation from my co-workers & $34(31.2 \%)$ & $66(60.6 \%)$ & $9(8.3 \%)$ & 0 & 0 \\
\hline 3 & My pay and benefit are very satisfying & $8(7.3 \%)$ & $42(38.5 \%)$ & $34(31.2 \%)$ & $25(22.9 \%)$ & 0 \\
\hline 4 & I am satisfied with the way my boss handles the workers & $16(14.7 \%)$ & $59(54.1 \%)$ & $25(22.9 \%)$ & $9(8.3 \%)$ & 0 \\
\hline 5 & My work is satisfying & $17(15.6 \%)$ & $67(61.5 \%)$ & $16(14.7 \%)$ & 0 & $9(8.3 \%)$ \\
\hline 6 & The chance to do something that makes use of my abilities & $17(15.6 \%)$ & $84(77.1 \%)$ & $8(7.3 \%)$ & 0 & 0 \\
\hline 7 & The feeling of accomplishment I get from the job & $26(23.9 \%)$ & $75(68.8 \%)$ & $8(7.3 \%)$ & 0 & 0 \\
\hline 8 & My workplace has a fair promotion policy & $17(15.6 \%)$ & $49(45 \%)$ & $34(31.2 \%)$ & 0 & $9(8.3 \%)$ \\
\hline 9 & The praise and credit for work well done & $9(8.3 \%)$ & $66(60.6 \%)$ & $25(22.9 \%)$ & $9(8.3 \%)$ & 0 \\
\hline 10 & My opportunities for personal advancement are not limited & $25(22.9 \%)$ & $58(53.2 \%)$ & $26(23.9 \%)$ & 0 & 0 \\
\hline 11 & I am satisfied with my pay and the amount of work I do & $25(22.9 \%)$ & $33(30.3 \%)$ & $25(22.9 \%)$ & $26(23.9 \%)$ & 0 \\
\hline 12 & The way my work is provides for steady employment & $24(22 \%)$ & $32(29.4 \%)$ & $35(32.1 \%)$ & $18(16.5 \%)$ & 0 \\
\hline 13 & Satisfied with working conditions & $16(14.7 \%)$ & $75(68.8 \%)$ & $9(8.3 \%)$ & $9(8.3 \%)$ & 0 \\
\hline 14 & The way my colleagues get along with each other & $16(14.7 \%)$ & $75(68.8 \%)$ & $18(16.5 \%)$ & 0 & 0 \\
\hline 15 & I am satisfied with the opportunities for promotion & $24(22 \%)$ & $49(45 \%)$ & $18(16.5 \%)$ & $9(8.3 \%)$ & $9(8.3 \%)$ \\
\hline
\end{tabular}

Table 2 reveals that the respondents are satisfied with the chance to do something that makes use of their abilities $84(77.1 \%)$; with my relationship with my supervisor $75(68.8 \%)$; the feeling of accomplishment I get from the job $75(68.8 \%)$; with working conditions $75(68.8 \%)$; the way my colleagues get along with each other $75(68.8 \%)$; with work $67(61.5 \%)$; with good cooperation from my co-workers $66(60.6 \%)$; and the praise and credit for work well done $66(60.6 \%)$

Table 3: Job Stress

\begin{tabular}{|c|c|c|c|c|c|c|}
\hline SN & Statement & $S A$ & $A$ & $U D$ & $D$ & $S D$ \\
\hline 1 & Lack of opportunity for growth or advancement in my Work & $9(8.3 \%)$ & $16(14.7 \%)$ & $8(7.3 \%)$ & $67(61.5 \%)$ & $9(8.3 \%)$ \\
\hline 2 & Too heavy of a work load & $18(16.5 \%)$ & $41(37.6 \%)$ & $25(22.9 \%)$ & $16(14.7 \%)$ & $9(8.3 \%)$ \\
\hline 3 & Work very long hours & $17(15.5 \%)$ & $33(30.3 \%)$ & 0 & $50(45.9 \%)$ & $9(8.3 \%)$ \\
\hline 4 & Uncertain or undefined job expectation & $34(31.2 \%)$ & $17(15.6 \%)$ & $8(7.3 \%)$ & $50(45.9 \%)$ & 0 \\
\hline 5 & Low salary & 0 & $40(36.7 \%)$ & $9(8.3 \%)$ & $51(46.8 \%)$ & $9(8.3 \%)$ \\
\hline 6 & Work interfering during personal or family time & $18(16.5 \%)$ & $48(44 \%)$ & $26(23.9 \%)$ & $17(15.6 \%)$ & 0 \\
\hline 7 & Unpleasant or dangerous physical conditions & $17(15.6 \%)$ & $33(30.3 \%)$ & 0 & $50(45.9 \%)$ & $9(8.3 \%)$ \\
\hline 8 & Job insecurity & $9(8.3 \%)$ & $41(37.6 \%)$ & 0 & $51(46.8 \%)$ & $8(7.3 \%)$ \\
\hline 9 & Problem with my supervisor & $26(23.9 \%)$ & $16(14.7 \%)$ & $8(7.3 \%)$ & $42(38.5 \%)$ & $17(15.6 \%)$ \\
\hline 10 & Inflexible hours & $26(23.9 \%)$ & $8(7.3 \%)$ & $25(22.9 \%)$ & $42(38.5 \%)$ & $8(7.3 \%)$ \\
\hline 11 & Unrealistic job expectations & $17(15.6 \%)$ & $8(7.3 \%)$ & $17(15.6 \%)$ & $56(54.1 \%)$ & $8(7.3 \%)$ \\
\hline 12 & Much work pressure & $34(31.2 \%)$ & $50(45 / 9 \%)$ & $25(22.9 \%)$ & 0 & 0 \\
\hline 13 & Frequently bring work home at night & $9(8.3 \%)$ & $32(29.4 \%)$ & $8(7.3 \%)$ & $43(39.4 \%)$ & $17(15.7 \%)$ \\
\hline 14 & $\begin{array}{l}\text { Work involve a lot of over-exposed from visual display units } \\
\text { (technology) }\end{array}$ & $27(24.8 \%)$ & $32(29.4 \%)$ & $16(14.7 \%)$ & $34(31.2 \%)$ & 0 \\
\hline 15 & Problems with my co-workers & 0 & $24(22 \%)$ & $8(7.3 \%)$ & $33(30.3 \%)$ & $44(40.4 \%)$ \\
\hline
\end{tabular}

Indications from Table 3 show respondents' perceptions on job stress. The respondents indentified much work pressure $84(77.1 \%)$ and work interfering during personal or family time $48(44 \%)$ as their major sources of job stress. Also, they slightly viewed work involving a lot of over-exposure from visual display units and too heavy of a work load as sources of job stress. However, they disagreed that lack of opportunity for growth or advancement in their work $67(61.5 \%)$; unrealistic job expectations 56(54.1\%); job insecurity $51(46.8 \%)$, and low salary $51(46.8 \%)$ as sources of job stress. 


\section{International Journal of Science and Research (IJSR) \\ ISSN (Online): 2319-7064}

Index Copernicus Value (2013): 6.14 | Impact Factor (2015): 6.391

Table 4: Organizational Citizenship Behavior

\begin{tabular}{|c|c|c|c|c|c|c|}
\hline$S N$ & Statements & $S A$ & $A$ & NEUT. & $D$ & $S D$ \\
\hline 1 & I do not abuse the rights of others & $52(47.7 \%)$ & $57(52.3 \%)$ & 0 & 0 & 0 \\
\hline 2 & I help orient new people even though it is not $\mathrm{r}$ & $43(39.4 \%)$ & $49(45 \%)$ & $9(8.3 \%)$ & $8(7.3 \%)$ & 0 \\
\hline 3 & I help others who have heavy loads & $18(16.5 \%)$ & $83(76.1 \%)$ & $8(7.3 \%)$ & 0 & 0 \\
\hline 4 & I am always ready to lend a helping hand to those arc & $18(16.5 \%)$ & $91(83.5 \%)$ & 0 & 0 & 0 \\
\hline 5 & My attendance to work is above the norm & $35(32.1 \%)$ & $50(45.9 \%)$ & $24(22 \%)$ & 0 & 0 \\
\hline 6 & I consider the impact of my act & $43(39.4 \%)$ & $49(45 \%)$ & $17(15.6 \%)$ & 0 & 0 \\
\hline 7 & I like to work extra days in my workplace & $26(23.9 \%)$ & $50(45.9 \%)$ & $16(14.7 \%)$ & $17(15.6 \%)$ & 0 \\
\hline 8 & I read and keep up with organization announcements, memos and so on & $34(31.2 \%)$ & $58(53.2 \%)$ & $8(7.3 \%)$ & 0 & $9(8.3 \%)$ \\
\hline 9 & I consume a lot of time complaining about trivial matters & $17(15.6 \%)$ & 0 & $8(7.3 \%)$ & $42(38.5 \%)$ & $42(38.5 \%)$ \\
\hline 11 & I always find fault with what the organization is doing & $18(16.5 \%)$ & $16(14.7 \%)$ & $25(22.9 \%)$ & $42(38.5 \%)$ & $8(7.3 \%)$ \\
\hline 12 & I try to take steps to prevent problems with othe & $44(40.4 \%)$ & $57(52.3 \%)$ & $8(7.3 \%)$ & 0 & 0 \\
\hline 13 & I consider obeying the rules and regulati & $26(23.9 \%)$ & $58(53.2 \%)$ & $16(14.7 \%)$ & 0 & $9(8.3 \%)$ \\
\hline 14 & I always focus on what is wrong rather than the positive side & $9(8.3 \%)$ & $16(14.7 \%)$ & $8(7.3 \%)$ & $42(38.5 \%)$ & $34(31.2 \%)$ \\
\hline 15 & ttend functions that are not requ & 0 & $42(38.5 \%)$ & $42(38.5 \%)$ & $16(14.7 \%)$ & $9(8.3 \%)$ \\
\hline 16 & I attend meetings that are not mandatory, but are considered impc & $9(8.3 \%)$ & $41(37.6 \%)$ & $34(31.2 \%)$ & $16(14.7 \%)$ & $9(8.3 \%)$ \\
\hline 17 & I willingly help others who have work related problems & $18(16.5 \%)$ & $67(61.5 \%)$ & $16(14.7 \%)$ & $8(7.3 \%)$ & 0 \\
\hline
\end{tabular}

Table 4 revealed the respondents' view on organizational citizenship behavior. In general, the respondents agreed to most of the organizational citizenship behavior statements. Some of the outstanding responses are; I do not abuse the right of others with a total positive rating of 109(100\%); I am always ready to lend a helping hand to those around me with a total positive rating of 109(100\%); I help others who have heavy loads $83(76.1 \%)$; and I am willingly help others who have work related problems 67(61.5\%).

\section{Testing of Hypotheses}

This segment presents the results of the formulated null hypotheses tested at 0.05 significance level.

Hypothesis one: There is no significant relationship between job satisfaction and job stress

Table 5: Relationship between job satisfaction and job stress

\begin{tabular}{|c|c|c|c|}
\hline Variables & Correlation $(r)$ & Prob. & Remark \\
\hline Job satisfaction & \multirow{2}{*}{0.612} & \multirow{2}{*}{0.000} & \multirow{2}{*}{ Significant } \\
\hline Job Stress & & & \\
\hline $\mathrm{N}$ & \multicolumn{2}{|l|}{109} & \\
\hline
\end{tabular}

Table 5 presents the relationship that exists between job satisfaction and job stress. The findings indicate that there is a positive relationship between job satisfaction and job stress. This was tested using correlation which value is 0.612 and is significant at $\mathrm{p}<0.05$. The null hypothesis which states that there is no significant relationship between job satisfaction and job stress is, therefore, rejected.

Hypotheses Two: There is no significant relationship between job satisfaction and organizational citizenship behavior.

Table 6: Relationship between job satisfaction and organizational citizenship behavior

\begin{tabular}{|c|c|c|c|}
\hline Variables & Correlation $(r)$ & Prob. & Remark \\
\hline Job satisfaction & \multirow{2}{*}{0.87} & 0.012 & Significant \\
\cline { 1 - 2 } $\begin{array}{c}\text { Organizational citizenship } \\
\text { behavior }\end{array}$ & \multicolumn{2}{|c|}{109} & \\
\hline $\mathrm{N}$ & & & \\
\hline
\end{tabular}

Table 7 above reveals the relationship between job satisfaction and organizational citizenship behavior. It shows that there is a significant positive relationship between job satisfaction of respondents and organizational citizenship behavior. This was tested using correlation which value is 0.87 and is significant at $\mathrm{p}<0.05$. Therefore, the null hypothesis is then rejected owing to the fact that job satisfaction has a positive influence on organizational citizenship behavior.

Hypothesis Three: There is no significant relationship between job stress and organizational citizenship behavior.

Table 7: Relationship between job stress and organizational citizenship behavior

\begin{tabular}{|c|c|c|c|}
\hline Variables & Correlation $(r)$ & Prob. & Remark \\
\hline Job stress & -0.74 & 0.002 & Significant \\
\cline { 1 - 1 } $\begin{array}{c}\text { Organizational citizenship } \\
\text { behavior }\end{array}$ & \multicolumn{2}{|c|}{109} & \\
\hline $\mathrm{N}$ & \multicolumn{2}{|c|}{-0.} & \\
\hline
\end{tabular}

Table 7 shows the relationship between job stress and organizational citizenship behavior. It indicates that there is a negative relationship between job stress and organizational citizenship behavior. This was tested using correlation which value is -0.74 and is significant at $p<0.05$. This suggests that job stress is having a negative impact on organizational citizenship behavior.

\section{Conclusion}

The current research explored the issue of job satisfaction, job stress and organizational citizenship behavior. The survey results show that the majority of the respondents are satisfied with their jobs. The study also revealed that much work pressure, work interfering during personal or family time; as well as the problem of coping with technology challenges are the major sources of job stress for the respondents. In relation to organizational citizenship behavior, the majority of the respondents positively agreed with most of the statements of organizational citizenship behavior. The results from the hypotheses revealed that there is a significant positive relationship between job satisfaction and job stress; between job satisfaction and organizational 


\section{International Journal of Science and Research (IJSR) \\ ISSN (Online): 2319-7064}

Index Copernicus Value (2013): 6.14 | Impact Factor (2015): 6.391

citizenship behavior; while there is a negative relationship between job stress and organizational citizenship behavior. This implies that the more the stress at work, the less likely librarians will be involved in the organizational citizenship behavior.

\section{References}

[1] J. García-Bernal, A. Gargallo-Castel, M. MarzoNavarro, and P. Rivera-Torres, Job satisfaction: empirical evidence of gender differences. Women in Management. Review, Vol. 20(4), pp. 279-288, 2005.

[2] M. Armstrong, A Handbo ok of Human resource Management Practice, Tenth Edition, Kogan Page Publishing, London, 264, 2006.

[3] C. N. Ikonne and U. D. Onuoha, Factors Influencing Job Satisfaction of Librarians in Federal and State University Libraries in Southern Nigeria. Open Access Library Journal, Vol. 2, pp. 1-9, 2015. e1337. DOI:10.4236/oalib.1101337

[4] K. A. Owolabi and M. O. Salaam, Job satisfaction and organizational commitment of academic librarians in Nigerian Universities. Library Herald, Vol. 48(2), 2010.

[5] S. Lim, Library informational technology workers: Their sense of belonging, role, job autonomy, and job satisfaction. The Journal of Academic Librarianship, Vol. 33(4), pp. 492-500, 2007.

[6] J. M. Leysen and J. M. K. Boydston, Job Satisfaction among Academic Cataloger Librarians. Collections and Technical services publications and papers, 2009. Available:

http://lib.dr.iastate.edu/cgi/viewcontent.cgi?article $=100$ 3\&context=libcat_pubs (June 12, 2016)

[7] R. F. AbuAlRub, Job stress, job performance, and social support among hospital nurses. Journal of Nursing Scholarship, Vol. 36(1), pp. 73-78, 2006.

[8] L. L. Larson, Internal auditors and job stress. Managerial Auditing Journal, Vol. 19(9), pp. 11191130, 2004

[9] P. Paillé, Stressful Work, Citizenship Behaviour and Intention to Leave the Organization in a High Turnover Environment: Examining the Mediating Role of Job Satisfaction, Journal of Management Research, Vol. 3(1), pp. E1, 1-14, 2011.

[10] J. P. Brun, and C. Lamarche, Évaluation des coûts du stress au travail. Rapport de recherche, Chaire de Gestion de la Santé et de la Sécurité au Travail. Université Laval, 2006.

[11] J. Park, Work stress and job performance. Perspectives, pp. 5-7, 2007.

[12] K. Mahalakshmi and S. A Sornam, Ergonomics and Techno stress among library professionals of engineering colleges of Anna University Singapore. Journal of Library \& Information Management, Vol. 4, pp. 89-102, 2011.

[13]A. Togia, A. Koustelios, and N. Tsigilis, Job satisfaction among Greek academic librarians. Library Information Science Research. Vol. 26(3), pp. 373-383, 2004.

[14] N. Davis-Millis, Technostress and the organization: A manager's guide to survival in the information age. Paper presented at the 67th Annual Meeting of the Music Library Association, 14 February, Boston,
Massachusetts, $\quad 1998$.

http://web.mit.edu/ninadm/www/mla.htm 2016)

[15]BBC News, Librarians 'suffer most stress, (UK, 2006), Available: http://news.bbc.co.uk/2/hi/uk/4605476.stm (June 14, 2016)

[16] E. McClellan, Stress and Cataloging Paraprofessionals in Academic and Public libraries in Florida. The Southeastern Librarian. Vol. 59(1), pp. 19-29, 2011.

[17] I. S. Babatope, The causes and effects of job related stress among Polytechnic Librarians in Delta State, Nigeria. International Journal of Library Science Vol. 2(1), pp. $1-\quad 5, \quad 2013$. DOI: $10.5923 /$ j.library.20130201.01

[18]E. B. Ajala,Work-related Stress among Librarians and Information Professionals in a Nigerian University. Library Philosophy and Practice, 2011.

[19]E. O. Merwin, Jr, Uptight in libraryland: a confirmation of stress in South Carolina academic libraries. Against the Grain, Vol. 15(1), pp. 28-34, 2003.

[20]D. Harrison, D. A. Newman, P. L. Roth, How important are job attitudes? Meta- Analytic comparisons of integrative behavioural outcomes and time sequences. Academy of Management Journal, Vol. 49, pp. 305$325,2006$.

[21]D. Organ, P. Podsakoff and S. MacKenzie, Organizational Citizenship Behavior. Its Nature, Antecedents and Consequences. Sage Publications, Thousand Oaks, 2006.

[22]N. S. Kandlousi, A. Ali, and A. Abdollahi, Organizational citizenship behaviour in concern of communication satisfaction: The role of the formal and informal communication. International Journal of Business and Management, Vol. 5(10), pp. 51-61, 2010.

[23]D. C. Fisher, Why do lay people believe that satisfaction and performance are correlated? Possible sources of a commonsense theory. Journal of Organizational Behaviour, Vol. 24(6), pp. 753-777, 2003. http://dx.doi.org/10.1002/job.219

[24] P. E. Spector, Industrial and organizational psychology: Research and practice $\left(2^{\text {nd }}\right.$ ed.) New York: John Wiley and Son, 2000.

[25] S. K. Khan, and M.Z. A. Rashid, The Mediating Effect of Organizational Commitment in the Organizational Culture, Leadership and Organizational Justice Relationship with Organizational Citizenship Behavior: A Study of Academicians in Private Higher Learning Institutions in Malaysia. International Journal of Business and Social Science Vol. 3(8) [Special Issue], pp. 83-91, 2012.

[26] P. M. Podskaff, B. S. McKenzie, J. B. Paine, D. G. Bacharach, Organizational citizenship behaviours: A critical review of the theoretical and empirical literature and suggestions for future research. Journal of Management, Vol. 26, pp.513-563, 2000. http://dx.doi.org/10.1177/014920630002600307] 